\title{
Strategi Mengajar Kimia (Lintas Minat) Melalui Modifikasi Leaderless Group Discussion (LGD)
}

\author{
Esdi Pangganti \\ SMA Negeri 4 Muara Teweh, Kalimantan Tengah, Indonesia
}

\begin{abstract}
Abstrak :Pelajaran kimia sering dianggap sebagai mata pelajaran yang sukar pada jurusan ilmu-ilmu alam (IA), lebih lagi jika diberikan pada jurusan ilmu-ilmu sosial (IIS) sebagai mata pelajaran lintas minat. Rata-rata siswa memperoleh nilai dibawah kriteria ketuntasan minimal (KKM) yaitu 75.Selain itu siswa terlihat kurang aktif dan tidak mempunyai motivasi yang baik. Hal ini dimungkinkan karena siswa merasa bahwa kimia merupakan mata pelajaran lintas minat, yang tidak mempunyai pengaruh signifikan pada penjurusan ilmu-ilmu sosial (IIS). Fenomena ini dapat diamati ketika proses PBM berlangsung beberapa siswa nampak kurang berminat dan tidak bisa memfokuskan dirinya untuk mempelajari materi yang sedang dipelajari, begitu juga saat proses diskusi berlangsung siswa cenderung tidak terlibat dan mempunyai respon yang rendah. Keberhasilan proses belajar mengajar salah satunya ditentukan oleh model atau metode mengajar yaitu bagaimana cara guru menyampaikan materi yang akan diajarkan. Leaderless Group Discussion adalah diskusi kelompok tanpa penunjukkan seorang pemimpin, yang memungkinkan setiap anggota kelompok memanifestasikan potensinya, dimodifikasi seperti Penjaga Stand Pameran. Dalam simulasi ini dapat diamati kemampuan seseorang dalam mengarahkan dan memimpin kelompok, kemampuan menjelaskan gagasan sehingga bisa diterima orang lain, kemampuan determinasi, dll.Hasil penerapan pembelajaran dengan pendekatan Modifikasi Leaderless Group Discussion (LGD) mampu menaikkan partisifasi siswa kelas XI jurusan Imu-ilmu Sosial (IIS) dalam belajar Kimia Lintas Minat mencapai 88,69\% dengan ketuntasan mencapai 89,66\% (26 orang).
\end{abstract}

\section{Kata Kunci: Kimia Lintas Minat, Modifikasi Leaderless Group Discussion (LGD), Stand Pameran}

\section{Pendahuluan}

Pelajaran kimia adalah salah satu mata pelajaran yang diberikan kepada siswa di SMA. Sejak diberlakukannya Kurikulum 2013 maka mata pelajaran kimia diberikan sebagai mata pelajaran pada kelompok C (Peminatan) dan kelompok D (Lintas Minat) dengan alokasi waktu masing-masing di kelas adalah 2 (dua) JP/minggu.

Pelajaran kimia sering dianggap sebagai mata pelajaran yang sukar pada jurusan ilmu-ilmu alam (IA), lebih lagi jika diberikan pada jurusan ilmu-ilmu sosial (IIS) sebagai mata pelajaran lintas minat. Hal ini dapat dilihat dari fenomena rendahnya nilai yang diperoleh siswa kelas XI IIS-4 SMA Negeri 4 Muara Teweh pada semester ganjil tahun pelajaran 2017/2018 saat mengikuti quis setelah berakhirnya pembelajaran mengenai tata nama senyawa alkana. Menurut catatan daftar nilai yang dibuat oleh penulis, rata-rata siswa memperoleh nilai dibawah kriteria ketuntasan minimal (KKM) kimia yang berlaku di SMA Negeri 4 Muara Teweh yaitu 75. Selain itu siswa terlihat kurang aktif dan tidak mempunyai motivasi yang baik dalam mempelajari tata nama senyawa alkana. Hal ini 
dimungkinkan karena siswa merasa bahwa kimia merupakan mata pelajaran lintas minat, yang tidak mempunyai pengaruh signifikan pada penjurusan ilmu-ilmu sosial (IIS). Fenomena ini dapat diamati ketika proses PBM berlangsung beberapa siswa nampak kurang berminat dan tidak bisa memfokuskan dirinya untuk mempelajari materi yang sedang dipelajari, begitu juga saat proses diskusi berlangsung siswa cenderung tidak terlibat dan mempunyai respon yang rendah. Beberapa perihal yang telah dikemukakan, sangat memprihatinkan bagi penulis sehingga menggugah penulis untuk melakukan penelitian sekaligus mengoreksi proses PBM yang selama ini diberikan oleh penulis.

Materi tata nama senyawa alkana diberikan oleh penulis sesudah menjelaskan materi tentang kekhasan atom karbon, dimana tata nama senyawa alkana merupakan bagian yang tidak terpisahkan dari materi tentang hidrokarbon dan minyak bumi. Berdasarkan pengamatan dan hasil penilaian yang dilakukan oleh penulis, diketahui bahwa sebagian besar siswa mengalami kesalahan dalam menentukan tata nama senyawa alkana. Hal ini dimungkinkan karena tata nama senyawa alkana ditentukan berdasarkan aturan-aturan khusus yang telah disusun oleh IUPAC (International Union Pure of Aplication Chemistry). Kesalahan tersebut diketahui penulis bermula ketika melakukan evaluasi pembelajaran mengenai tata nama senyawa alkana, dimana beberapa siswa menjawab soal seperti yang ditunjukkan pada Gambar 1 berikut :

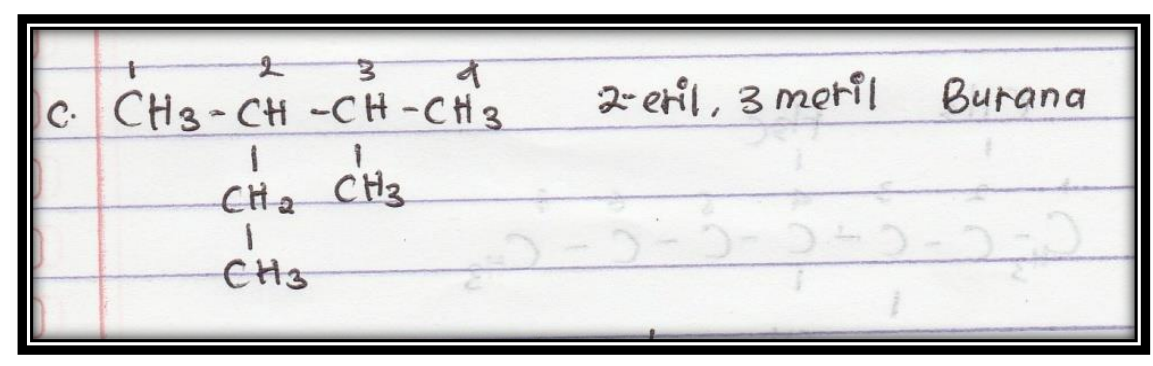

Gambar 1. Pola Jawaban Salah Siswa

Kesalahan siswa sebagaimana gambaran tersebut di atas diperkuat dengan hasil wawancara dengan siswa, mengenai jawaban yang diberikan tersebut.

\section{Metode Penelitian}

Model penelitian ini mengacu pada model penelitian tindakan kelas dari Mc.Kemmis dan Mc.Taggart, yang dalam kegiatan menggunakan siklus sistem spiral. Masing-masing siklus terdiri dari empat komponen pokok yaitu perencanaan, perlakuan atau tindakan, pengamatan dan refleksi. Keempat komponen tersebut menunjukkan sebuah siklus atau kegiatan berkelanjutan seperti pada gambar berikut: 


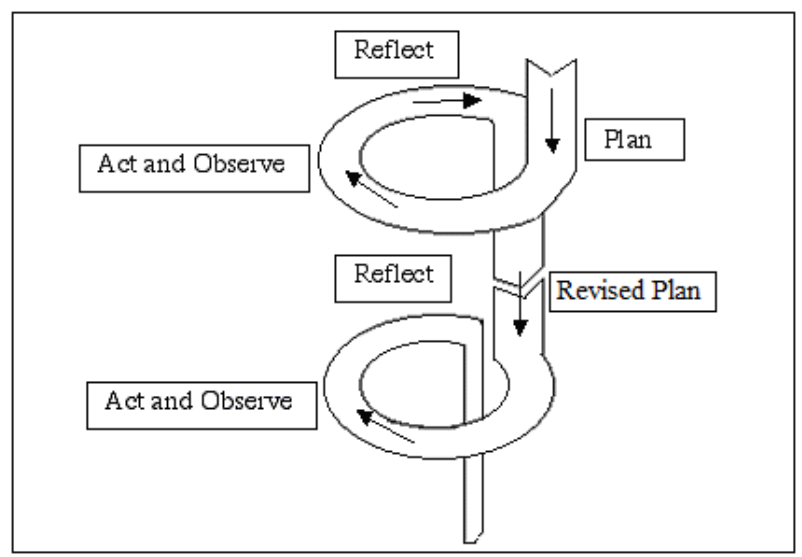

\section{Gambar 2. Model Penelitian Tindakan Kelas dari Kemmis dan Mc Taggart}

Berdasarkan prosedur penelitian di atas, maka tindakan penelitian tindakan kelas dilakukan untuk meningkatkan kemampuan menentukan tata nama senyawa alkana serta partisipasi belajar siswa yang dimulai dari perencanaan, perlakuan dan pengamatan, dilanjutkan dengan refleksi. Setelah melalui refleksi dan mendapatkan data mengenai pembelajaran yang dirasa masih belum maksimal, maka penulis perlu merencanakan peningkatan kemampuan dan partisipasi belajar siswa tersebut pada siklus selanjutnya.

\section{Teknik Pengumpulan Data}

Sesuai dengan sumber data yang digunakan dalam penelitian ini, maka teknik pengumpulan data yang digunakan antara lain:

\section{Observasi}

Observasi dilakukan untuk mengamati partisipasi dalam pelaksanaan dan perkembangan pembelajaran lintas minat kimia yang dilakukan oleh para siswa. Pengamatan dilakukan sebelum, selama, dan sesudah siklus penelitian berlangsung. Jenis observasi yang digunakan adalah observasi partisipan artinya peneliti ikut terlibat dalam proses pembelajaran (tindakan). Data dicatat oleh peneliti dan observer.

Tabel 1. Lembar Observasi Partisipasi Siswa

\begin{tabular}{|c|c|c|}
\hline Indikator Partisipasi Siswa & Skor & Keterangan \\
\hline 1. Berbicara & & \\
\hline 2. Bertanya & & \\
\hline 3. Menjawab & & \\
\hline 4. Perhatian & & \\
\hline 5. Tampil & & \\
\hline angan: & $5=$ Sangat Baik & $2=$ Kurang \\
\hline & $4=$ Baik & $1=$ Sangat Kurang \\
\hline & $3=$ Cukup & \\
\hline
\end{tabular}




\section{Teknik Evaluasi/ Tes}

Tes digunakan untuk mengetahui Kemampuan siswa dalam menentukan tata nama alkana pada pelaksanaan tindakan. Tes yang digunakan adalah soal uraian yang digunakan untuk mengumpulkan data tentang kemampuan awal dan hasil pembelajaran dengan teknik modifikasi leaderless group discussion. Adapun indikator tes kemampuan dalam menentukan tata nama alkana adalah sebagai berikut:

Tabel 3. Indikator Tes Kemampuan Menentukan Tata Nama Alkana

\begin{tabular}{|c|c|c|c|c|}
\hline \multirow[b]{2}{*}{ Indikator } & \multicolumn{3}{|c|}{ Skor Penilaian } & \multirow{2}{*}{$\begin{array}{l}\text { Total } \\
\text { Skor }\end{array}$} \\
\hline & Terampil & Ketepatan & $\begin{array}{l}\text { Menguasai } \\
\text { Konsep }\end{array}$ & \\
\hline $\begin{array}{l}\text { Menentukan rantai } \\
\text { terpanjang Alkana (T1) }\end{array}$ & & & & \\
\hline $\begin{array}{lrr}\begin{array}{l}\text { Menentukan } \\
\text { terpanjang }\end{array} & \text { sesuai } & \text { rantai } \\
\text { homolog alkana }(\mathrm{T} 2) & \end{array}$ & & & & \\
\hline $\begin{array}{l}\text { Menentukan awal penomoran } \\
\text { pada rantai utama (T3) }\end{array}$ & & & & \\
\hline $\begin{array}{l}\text { Menentukan cabang (Alkil) } \\
\text { (T4) }\end{array}$ & & & & \\
\hline $\begin{array}{l}\text { Membedakan nama-nama } \\
\text { alkil (T5) }\end{array}$ & & & & \\
\hline $\begin{array}{l}\text { Mengurutkan nama-nama } \\
\text { alkil sesuai abjad (T6) }\end{array}$ & & & & \\
\hline Menuliskan awalan bahasa & & & & \\
\hline $\begin{array}{l}\text { Yunani pada alkil yang } \\
\text { berjumlah lebih dari satu } \\
\text { (T7) }\end{array}$ & & & & \\
\hline $\begin{array}{l}\text { Menuliskan letak alkil pada } \\
\text { rantai karbon (T8) }\end{array}$ & & & & \\
\hline $\begin{array}{l}\text { Menuliskan nama alkana } \\
\text { sesuai rumus } \\
\text { bangun/strukturnya (T9) }\end{array}$ & & & & \\
\hline
\end{tabular}

Keterangan: $3=$ Bisa $2=$ Kurang Bisa $1=$ Tidak Bisa

\section{Dokumentasi}

Dokumentasi merupakan upaya untuk memberikan gambaran bagaimana sebuah penelitian tindakan kelas dilakukan. Dokumentasi yang digunakan adalah dokumentasi non tes yaitu dokumentasi berupa gambar atau foto proses belajar mengajar saat penelitian dilaksanakan.

\section{Teknik Analisis Data}

Data yang tersedia dari pengumpulan data perlu dianalisis, sedangkan untuk menganalisis data tersebut perlu digunakan teknik analisis data sehingga data yang ada dapat dimanfaatkan dengan baik. Data penelitian ini dianalisis dengan menggunakan teknik analisis data sebagai berikut: 


\section{Analisis deskriptif komparatif}

Analisis deskriptif komparatif dilakukan dengan membandingkan antara kondisi awal sebelum dilakukannya tindakan dengan hasil yang diperoleh pada siklus I dan siklus II sehingga dapat dilihat adanya perbedaan sebelum dan sesudah dilakukannya tindakan.

\section{Analisis data kuantitatif}

Analisis data kuantitatif digunakan untuk mengolah hasil belajar siswa yang diperoleh dari tes formatif. Data kuantitatif yang digunakan adalah kuantitatif sederhana yang berupa penghitungan nilai rata-rata, nilai tertinggi, nilai terendah, dan persentase jumlah siswa yang mencapai batas ketuntasan. Dari informasi ini dapat diketahui sampai sejauh manakah keberhasilan siswa dalam proses belajar mengajar.

\section{Analisis data kualitatif}

Analisis kualitatif berupa catatan lapangan yang disajikan secara rinci dan lengkap selama proses penelitian berlangsung. Analisis data kualitatif diperoleh berdasarkan hasil observasi, refleksi dari tiap-tiap siklus, dan membandingkan kinerja siswa maupun guru dalam hasil pengamatan dengan parameter atau teori tertentu.

\section{Indikator Keberhasilan Penelitian Tindakan}

Indikator Keberhasilan tindakan dalam upaya meningkatkan kemampuan menentukan tata nama senyawa alkana pada pelajaran lintas minat kimia menggunakan teknik modifikasi leaderless group discussion siswa kelas XI IIS 4 SMA Negeri 4 Muara Teweh, Kabupaten Barito Utara, Provinsi Kalimantan Tengah adalah sebagai berikut:

1. 80\% siswa berpartisipasi aktif dalam interaksi, mengajukan pertanyaan, menjawab pertanyaan, memusatkan perhatian, serta tampil ke depan kelas.

2. $80 \%$ siswa mencapai KKM 75

3. Guru mengubah cara pembelajaran dari teacher center (berpusat pada guru) menjadi student center (berpusat pada siswa).

\section{Hasil Penelitian Dan Pembahasan}

Berdasarkan penelitian pada kelas XI IIS 4 SMA Negeri 4 Muara Teweh Pada Semester Ganjil Tahun Pelajaran 2017/2018 yang terdiri dari 11 anak perempuan dan 18 anak laki-laki, dapat diketahui data sebagai berikut:

Tabel 1. Persentase Ketuntasan Siswa dalam LGD PERSENTASE KETUNTASAN (MENCAPAI KKM 75)

$55,17 \%$ (16 orang) $\quad 89,66$ (26 orang)


Berdasarkan data pada Tabel 1 di atas, dapat diketahui bahwa pada akhir siklus ke-2 persentase ketuntasan siswa mencapai 89,66\% atau meningkat sebesar 34,49 poin dari Siklus ke-1 sebesar $55,17 \%$. Hal ini membuktikan bahwa Modifikasi LGD efektif untuk meningkatkan kemampuan menentukan tata nama senyawa alkana pada mata pelajaran kimia lintas minat.

Tabel 2. Persentase Partisipasi Siswa dalam LGD

\begin{tabular}{lllll} 
INDIKATOR & \multicolumn{3}{l}{ PERSENTASE PARTISIFASI SISWA } \\
PARTISIFASI SISWA & Pratindakan & Siklus-1 & Siklus 2 \\
\cline { 3 - 4 } & 54,48 & 65,52 & 82,07 \\
1. Berbicara & 55,17 & 59,31 & 88,28 \\
2. Bertanya & 55,17 & 58,62 & 89,66 \\
3. Menjawab & 49,66 & 68,97 & 95,17 \\
4. Perhatian & 41,38 & 55,86 & 88,28 \\
5. Tampil & $\mathbf{5 1 , 1 7}$ & $\mathbf{6 1 , 6 6}$ & $\mathbf{8 8 , 6 9}$ \\
RERATA & & & \\
\hline
\end{tabular}

Berdasarkan data pada Tabel 1 di atas, dapat diketahui bahwa pada akhir siklus ke-2 persentase partisifasi siswa mencapai 88,69\% atau meningkat sebesar 27,03 poin dari Siklus ke-1 sebesar $61,66 \%$. Hal ini membuktikan bahwa Modifikasi LGD efektif dipakai untuk meningkatkan partisifasi siswa dalam meningkatkan kemampuan menentukan tata nama senyawa alkana pada mata pelajaran kimia lintas minat.

\section{Kesimpulan}

Melalui tindakan tersebut guru berhasil melaksanakan pembelajaran kimia lintas minat yang menyenangkan sehingga prestasi belajar kimia lintas minat dapat meningkat. Selain itu, dapat meningkatkan kinerja guru dalam melaksanakan pembelajaran yang efektif dan menarik.

Kegiatan belajar mengajar di kelas yang berpusat pada siswa (student center) sehingga siswa aktif dalam proses pembelajaran baik dalam diskusi atau kerja kelompok, presentasi, tanya jawab. Kegiatan ini dapat melatih siswa dalam bekerja sama dan menumbuhkan semangat kebersamaan di dalam kelompok belajar. Suasana pembelajaran santai, menyenangkan, dan sesuai dengan keinginan siswa sehingga membuat siswa lebih berminat dan nyaman dalam belajar. Hal ini terlihat dari semangat dan antusiasme siswa dalam mengikuti pelajaran terus mengalami peningkatan.

Siswa mampu memahami materi yang telah diberikan dan lebih percaya diri dengan kemampuannya. Hal ini terjadi karena siswa yang mulanya belum memahami benar materi yang disampaikan oleh guru dapat menanyakannya lebih lanjut dan leluasa baik secara langsung kepada guru maupun teman yang menjadi penjaga stand. Hasil belajar tersebut dinyatakan tuntas karena secara umum pencapaian hasil belajar siswa berada di atas standar ketuntasan minimal 75 dan mengalami peningkatan dari siklus ke-1 sampai siklus ke-2. Hal ini menunjukkan 
bahwa secara umum siswa telah memahami materi menentukan tata nama Alkana yang disajikan dengan baik pada proses belajar mengajar yang menggunakan model modifikasi Leaderless Group Disscussion (LGD).

\section{Daftar Rujukan}

Sardiman A. M. 2004. Interaksi dan Motivasi Belajar Mengajar. Jakarta: Raja Grafindo Persada.

Slameto. 2003. Belajar dan Faktor-faktor yang Mempengaruhinya. Jakarta: Rineka Cipta.

Sugiyanto. 2008. Model-model Pembelajaran Inovatif. Surakarta: Panitia Sertifikasi.

Suharsimi Arikunto, Suhardjono, dan Supardi. . Penelitian Tindakan Kelas. Jakarta: Penerbit Bumi Aksara.

Sumadi Suryabrata. 2010. Psikologi Pendidikan. Jakarta: Rajawali Pers.

Trianto. 2009. Mendesain Model Pembelajaran Inovatif-Progresif. Jakarta: Prestasi Pustaka Publisher.

https://www.kompasiana.com/risnajayanti/keefektifan-leaderless-groupdiscussion-dalam-assessment-center_54f921dba33311f1068b470d diunduh tgl. 01.11.2017

http://careernews.id/issues/view/3648-LGD-dan-FGD-Tampak-Sama-Nyata-Beda diunduh tgl. 01.11.2017 